\title{
Chimpanzees (Pan troglodytes) Flexibly Use Introduced Species for Nesting and Bark Feeding in a Human-Dominated Habitat
}

\author{
Maureen S. McCarthy ${ }^{1,2}$ • Jack D. Lester ${ }^{2}$. \\ Craig B. Stanford ${ }^{1}$
}

Received: 13 May 2016 / Accepted: 8 July 2016 / Published online: 16 September 2016

(C) The Author(s) 2016. This article is published with open access at Springerlink.com

\begin{abstract}
As habitat loss and fragmentation place growing pressure on endangered nonhuman primate populations, researchers find increasing evidence for novel responses in behavior. In western Uganda between the Budongo and Bugoma Forests, chimpanzees (Pan troglodytes schweinfurthii) inhabit a mosaic landscape comprising forest fragments, human settlements, and agricultural land. We recorded nests and feeding evidence of unhabituated chimpanzees in this region over a 12-mo period. We found extensive evidence of nesting in introduced tree species, including eucalyptus (Eucalyptus grandis), guava (Psidium guajava), cocoa (Theobroma cacao), and Caribbean pine (Pinus caribaea). In addition, we found instances of ground nesting, nest reuse, and composite nests constructed from branches of multiple trees. This evidence may indicate a lack of suitable nesting trees or attempts by chimpanzees to nest in areas of riparian forest that allow them to avoid human detection. We also found new evidence for eucalyptus bark feeding by chimpanzees. Such evidence suggests chimpanzees respond flexibly to mitigate anthropogenic pressures in human-dominated landscapes. The limits of such flexibility remain unknown. Further research is needed to examine systematically the factors influencing the use of such resources and to understand better the extent to which chimpanzees can persist while relying on them.
\end{abstract}

Keywords Bark feeding $\cdot$ Chimpanzee $\cdot$ Eucalyptus nesting $\cdot$ Fragmented habitat $\cdot$ Pan troglodytes

Handling Editor: Matthew McLennan

Maureen S. McCarthy

maureen_mc@eva.mpg.de

1 Department of Biological Sciences, Dana and Dornsife College of Letters, Arts, and Sciences, University of Southern California, Los Angeles, CA 90089-0371, USA

2 Department of Primatology, Max Planck Institute for Evolutionary Anthropology, 04103 Leipzig, Germany 


\section{Introduction}

Anthropogenic habitat changes can impact primate behavior in a number of ways. For example, great apes may alter their activity budgets and travel patterns in humandisturbed environments (Ancrenaz et al. 2014; Campbell-Smith et al. 2011; Cibot et al. 2015; Hockings et al. 2012; Krief et al. 2014). They may also respond to habitat changes by incorporating new species into their diets. For example, orangutans feed on oil palm trees in plantations in Borneo (Ancrenaz et al. 2015). Chimpanzees at numerous research sites under varying levels of human impact also consume cultivars (Bessa et al. 2015; Hockings and McLennan 2012; Hockings et al. 2009; Krief et al. 2014; McLennan 2013; Reynolds 2005). Additionally, mountain gorillas feed on eucalyptus bark in tree plantations (Rothman et al. 2006). Such behavioral responses provide insights into great ape cognition and evolution, and can provide valuable data to guide conservation efforts for remaining populations (Hockings et al. 2015).

Chimpanzees and other great apes may also alter their nesting patterns in response to human disturbance, e.g., by varying nest height. For example, a higher prevalence of ground nesting has been reported where human density was lower, suggesting chimpanzees may nest more freely on the ground when human pressure does not inhibit this behavior (Hicks 2010; Last and Muh 2013). In contrast, another study reported more ground nesting at times when human pressure was higher (Tagg et al. 2013). The authors suggested ground nesting in this context may be enabled by the chimpanzees' increased use of swamp forest, a habitat rarely entered by humans, thereby facilitating ground nesting and lessening the likelihood of human detection. Such pressure could hypothetically drive low nest heights as well. Low nests and ground nests could also result from a limited availability of suitable nesting trees, however, leading individuals to nest in smaller, less sturdy trees or on the ground by necessity. Therefore, although night ground nesting has been reported at a number of research sites (Furuichi and Hashimoto 2000; Koops et al. 2012; Pruetz et al. 2008), variations in its frequency may sometimes be related to human disturbance for numerous reasons.

Other changes to nesting patterns may be expected to occur in human-impacted great ape habitats as well. As favored nest tree species are felled, other introduced species may replace them, either by necessity, due to the adoption of new nest tree preferences, or both. (In this article we use the term introduced species to refer broadly to exotic, nonnative species that are grown for food, timber, or fuel wood.) For example, Bornean orangutans, as well as chimpanzees in Guinea-Bissau, nest in oil palm trees (Ancrenaz et al. 2015; Sousa et al. 2011). Lower nest tree availability may also lead great apes to reuse nests, as low availability of fresh leaves may contribute to nest reuse (Fruth and Hohmann 1996; Wrangham 1992). A lower availability of tall, sturdy nest trees in logged habitat may also lead to the construction of composite nests composed of smaller, less sturdy trees and other vegetation. Few studies have documented great ape nesting patterns in human-disturbed habitat, however, and the use of introduced species for nesting has rarely been reported to date.

In a roughly $1200-\mathrm{km}^{2}$ area in western Uganda between the Budongo and Bugoma Forests, chimpanzees (Pan troglodytes schweinfurthii) inhabit small forest fragments. Using noninvasively collected fecal samples for genetic analysis, a recent study identified a total chimpanzee population numbering 256 (95 \% CI: 246-321) or 319 (288-357) chimpanzees, depending on the estimator used (McCarthy et al. 2015). 
Genotypes clustered in nonoverlapping polygons distributed throughout the study area, suggesting the presence of a minimum of nine distinct chimpanzee communities. These chimpanzees inhabit mostly the unprotected riparian forests in this area, but range through the agricultural matrix and consume cultivars from local homesteads and gardens (McLennan 2013), sometimes coming into conflict with their human neighbors (McLennan and Hill 2012).

These conflicts appear more common as human pressures increase (McLennan and Hill 2012). Human population density is estimated at 156.6 and 113.3 residents per $\mathrm{km}^{2}$ respectively in Hoima and Masindi Districts, the two governmental districts comprising this region (UBOS 2014). Uganda's human population growth rate is $3.8 \%$, one of the highest globally (CIA 2013). Much of the human population relies on subsistence and commercial agriculture (FAO 2010), and $90 \%$ of Ugandans rely on wood fuel as a main energy source (MWLE 2002). These growing pressures have led to a $37 \%$ forest loss in Uganda from 1990 to 2010 (FAO 2010), with $>130 \mathrm{~km}^{2}$ of forest loss in the region between Budongo and Bugoma in the past several decades (Twongyirwe et al. 2015). Plantation forests have replaced natural forests in some areas and play an integral role in modern forestry policy in Uganda (Turyahabwe and Banana 2008). However, the ability of plantation forests to reduce reliance on natural forests is questionable (Ainembabazi and Angelsen 2014).

Given the ongoing chimpanzee habitat loss in this region and the increasing prevalence of introduced species, it is critical to understand how Endangered chimpanzees respond to such habitat changes to better predict their likelihood of survival and to devise appropriate conservation strategies. The purpose of this study was to document nesting patterns among chimpanzees in this fragmented forest landscape to determine how nesting preferences may reflect responses to anthropogenic habitat changes, including the increasing prevalence of introduced species. We hypothesized that chimpanzee nesting patterns would reflect behavioral responses to habitat disturbance. In particular, we predicted that chimpanzees would nest in introduced species, reuse nests, and construct nests from multiple trees. Further, we predicted that chimpanzees would nest at low heights or on the ground. In addition, we opportunistically documented evidence of a novel feeding behavior by chimpanzees in this environment.

\section{Methods}

\section{Study Area and Subjects}

We collected data in Hoima and Masindi Districts, Uganda in the corridor area between the Budongo and Bugoma Forests $\left(1^{\circ} 37^{\prime}-1^{\circ} 68^{\prime} \mathrm{N}\right.$ and $31^{\circ} 1^{\prime}-31^{\circ} 6^{\prime} \mathrm{E}$; Fig. 1). Both forests are medium-altitude, moist semideciduous forests measuring slightly over $400 \mathrm{~km}^{2}$ (Eggeling 1947; Langdale-Brown et al. 1964). The region between these forests, which measures roughly $40 \mathrm{~km}$ long by $30 \mathrm{~km}$ wide, is a mosaic of villages, agricultural land, grasslands, and riparian forest fragments. In the past several decades, human populations have increased substantially in this region, leading to the widespread conversion of unprotected riparian forests for subsistence and commercial agriculture (FAO 2010; Mwavu and Witkowski 2008; Twongyirwe et al. 2015). Chimpanzees are broadly distributed in the forested habitat of this region (McCarthy 


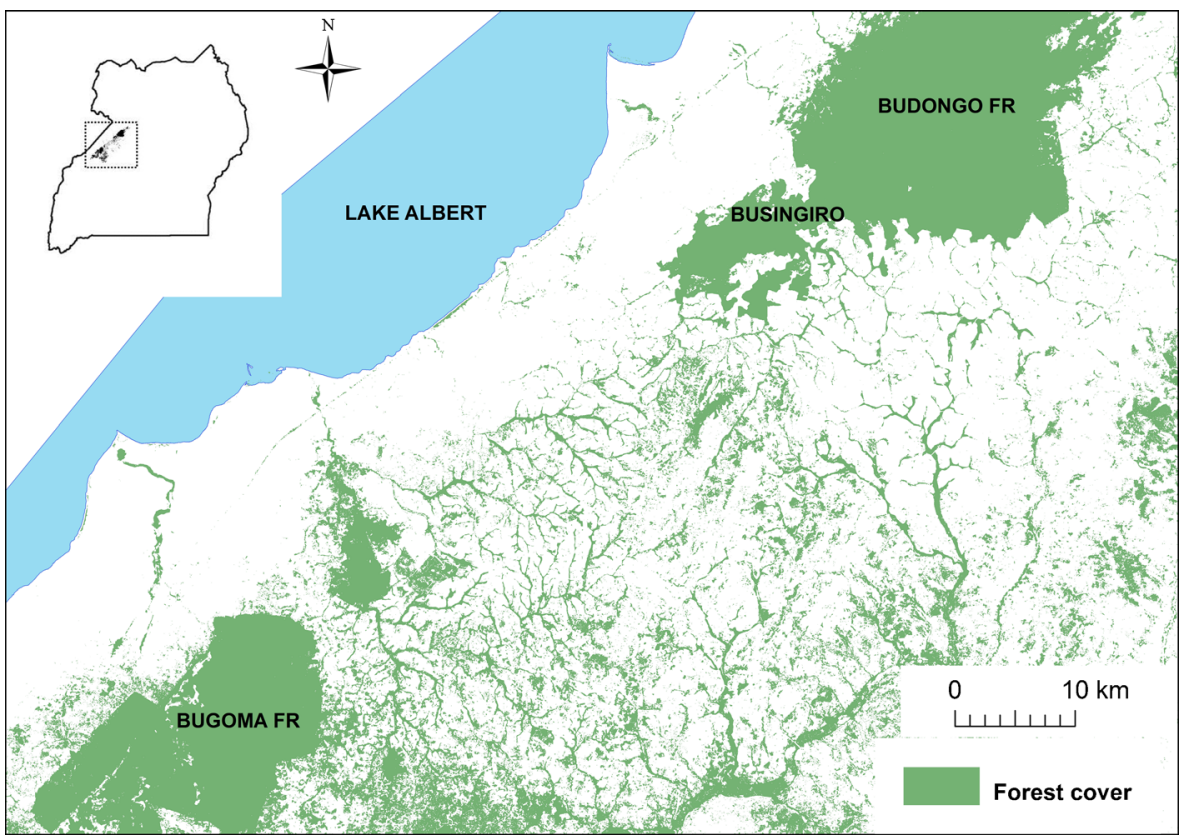

Fig. 1 Map of the study area in Uganda. The inset map displays the landscape's location within Uganda. Green indicates forest cover during the study period (Hansen et al. 2013).

et al. 2015; McLennan 2008) and are mostly unhabituated to researcher presence, though they have frequent interactions with their human neighbors (McLennan 2008; McLennan and Hill 2012; McLennan et al. 2012).

\section{Data Collection}

We collected data on chimpanzee nests and feeding traces opportunistically throughout the study area from October 2012 through September 2013 as part of a broader study examining chimpanzee distribution patterns throughout this landscape. We used Landsat satellite imagery to identify the forest fragments located within the boundaries of a given village, and searched permitted and accessible forest fragments within the boundaries of that village. We divided the study area into a grid of $1 \mathrm{~km}$ by $1 \mathrm{~km}$ cells and recorded when we searched any part of a cell (McCarthy et al. 2015). We determined chimpanzee presence based on prior survey evidence (McLennan 2008) and via informal discussion with local inhabitants. Strictly systematic survey methods were impractical in this human-dominated habitat comprising mainly villages and privately owned farms. Instead, we focused search effort in forest fragments on villages within which the privately owned forests were located. In accordance with local customs, before searching a forest fragment we gained permission from the chairperson of the village in which the forest fragment was located, and from individuals identifying themselves as landowners of the forest fragment.

When we encountered nests, we recorded the spatial location of each nest using a Garmin GPSMap® 60CSx. We classified each nest as fresh (all leaves green), recent (some green and some brown leaves), or old (only brown, dead leaves) (Tutin and 
Fernandez 1984). For each nest, we recorded the tree species name. We also measured tree diameter at breast height (DBH), as well as estimating nest height and tree height using a Bresser® laser Range Finder 800 . We noted nests that were constructed using branches from multiple species (composite nests), including the number of plants used for construction and the species of each plant. For ground nests, we recorded whether the nest appeared to be a night nest (well constructed with a thick cushion of support and circular construction) or a day nest (poorly constructed with thin cushioning and noncircular construction) (Brownlow et al. 2001; Koops et al. 2007; Last and Muh 2013; Stanford and O'Malley 2008). We also recorded the general habitat type in which each nest was found. In addition, we recorded instances in which nests displayed signs of reuse, such as when a previously recorded nest showed signs of fresh use, or when a nest was encountered with fresh leaves woven over a bed of decayed leaves.

We also recorded any feeding traces encountered throughout the study area grid. For each feeding trace, we recorded the spatial location and the species of vegetation consumed. Humans as well as baboons (Papio anubis) can leave behind cultivar feeding traces that superficially resemble those produced by chimpanzees. Baboons have mostly been eradicated from the study area, however. In addition, chimpanzee feeding traces were typically easy to identify because they were accompanied by other identifying signs such as chimpanzee knuckle prints, nests, discarded wadges (boluses of chewed vegetation), or feces. For instances in which the consumer of a food item was uncertain, we did not record the feeding trace.

\section{Chimpanzee Community Affiliations and Minimum Home Ranges}

Based on previously published genetic evidence (McCarthy et al. 2015), we associated nesting and feeding patterns with the putative chimpanzee communities in which those behaviors occurred. We constructed $100 \%$ minimum convex polygons (MCPs) for published chimpanzee genotypes found in association using the Minimum Convex Polygon Plugin for QGIS version 2.4.0 (Quantum GIS 2014). We used these MCPs to represent minimum home ranges for each putative chimpanzee community. We then mapped nesting and feeding evidence using QGIS to determine the distribution of nesting and feeding traces associated with each community's minimum home range. Further details regarding these chimpanzee genotypes and their distributions are available in McCarthy et al. (2015).

\section{Data Analysis}

We analyzed the frequency of nesting across nest ages, habitat types, and tree species. We also examined the distribution of nest tree species for fresh nests only, however, because of the likely variability in nest decay rates across species. We calculated mean nest height as well as the frequency of nest reuse, composite nests, and ground nests. For plantations containing eucalyptus nests, we calculated plantation area using satellite imagery in QGIS version 2.4.0 (Quantum 2014) as well as total forested area within the MCPs of putative chimpanzee communities containing eucalyptus nests (Hansen et al. 2013). We also calculated the straight line distance between these eucalyptus nests and the nearest patch of natural forest using spatial measuring tools in QGIS version 2.4.0 
(Quantum 2014). We calculated the mean distance between these eucalyptus plantations and the nearest natural forest.

\section{Ethical Note}

We carried out data collection in accordance with the legal requirements of Uganda, and with the permission of the Uganda National Council for Science and Technology, the Uganda Wildlife Authority, and the National Forestry Authority of Uganda. Additional permissions were granted by local landowners where applicable, as described previously. Because data collection was entirely noninvasive and required no contact with the chimpanzees, ethical consent was not necessary for this project.

\section{Results}

\section{Chimpanzee Nests}

We recorded a total of 881 nests throughout the study area (Fig. 2). Of these, 489 (56\%) were fresh nests, 269 (31\%) were recent nests, $105(12 \%)$ and were old nests. For an additional 18 nests (2\%), ages could not be estimated. Among the seven

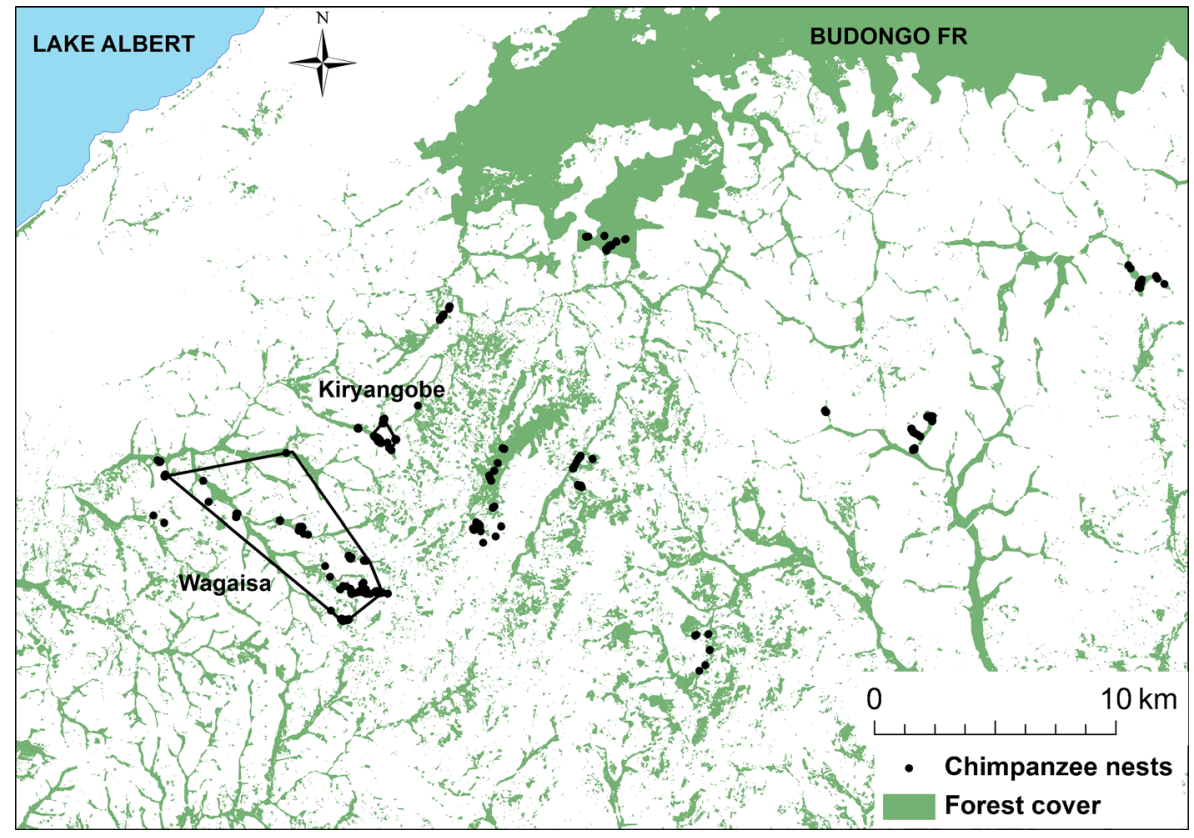

Fig. 2 Chimpanzee nest locations throughout the study area, western Uganda, from October 2012 to September 2013. Individual chimpanzee nests are indicated as black circles. Not all nests are visible because of map scaling. MCPs for Wagaisa and Kiryangobe are indicated by polygons. Green indicates forest cover during the study period (Hansen et al. 2013). 
recorded habitat types, nests were most commonly encountered in riparian forests (270 nests; $31 \%$ of total nests; Table I).

Mean nest height was $10.9 \mathrm{~m}(\mathrm{SD}=5.5 \mathrm{~m}$; range: $0-33 \mathrm{~m}$; Table II). We recorded a total of 19 ground nests ( $2 \%$ overall), including both those classified as day nests and as night nests. Of these, we classified $11(1 \%)$ as night nests. Fifty-nine nests $(7 \%)$ were composite nests constructed with branches from more than one plant. In addition, 35 nests (4\%) displayed evidence of reuse.

We recorded nests in a total of 49 plant species. When we considered nests irrespective of age, Eucalyptus grandis was the most common nest tree species, followed by Macaranga schweinfurthii and Pseudospondias microcarpa (Table III). The same three species were the most commonly encountered for fresh nests, though nests of Macaranga schweinfurthii were encountered slightly more than Eucalyptus overall. In addition to eucalyptus, the chimpanzees used six other introduced species for nesting: cocoa (Theobroma cacao), jackfruit (Artocarpus heterophyllus), mango (Mangifera indica), Caribbean pine, (Pinus caribaea), guava (Psidium guajava), and sugar cane (Saccharum officinarum). Nests in introduced species composed $22 \%$ of total nests overall (Table III).

Owing to the high overall prevalence of eucalyptus nests, we further examined characteristics of nests in this species. We encountered eucalyptus nests in 11 small eucalyptus plantations in the study region. These plantations containing chimpanzee nests were associated with the MCPs of two putative chimpanzee communities (Fig. 2), and covered a total area of $12.3 \mathrm{ha}$. In contrast, total forest cover for the minimum home ranges of these chimpanzee communities measured 643 ha (Hansen et al. 2013). Therefore, fresh eucalyptus nests accounted for $20 \%$ of nests overall and $14 \%$ of fresh nests while eucalyptus trees accounted for $c a .2 \%$ of forest cover in the minimum home ranges of these chimpanzee communities. Four additional eucalyptus plantations located near or within known areas of chimpanzee habitat use failed to yield chimpanzee nests during the study period.

We further investigated whether eucalyptus nesting may have been associated with a particularly low availability of suitable nesting trees in the vicinity. The mean distance between eucalyptus plantations used for nesting and the nearest patch of natural forest was $48.2 \mathrm{~m}(N=11$; range: $0-240 \mathrm{~m})$. It was beyond the scope of this study to examine nest tree availability systematically throughout the corridor landscape.

Table I Habitat types in which chimpanzee nests were encountered in Hoima and Masindi Districts, Uganda from October 2012 to September 2013

\begin{tabular}{lll}
\hline Habitat type & No. of nests & Proportion of total nests \\
\hline Plantation & 198 & 0.22 \\
Permanently inundated swamp forest & 202 & 0.22 \\
Med. alt. rain forest & 174 & 0.19 \\
Forest edge & 6 & 0.01 \\
Farmland & 5 & 0.01 \\
Riparian forest & 290 & 0.32 \\
Woodland & 26 & 0.03 \\
\hline
\end{tabular}




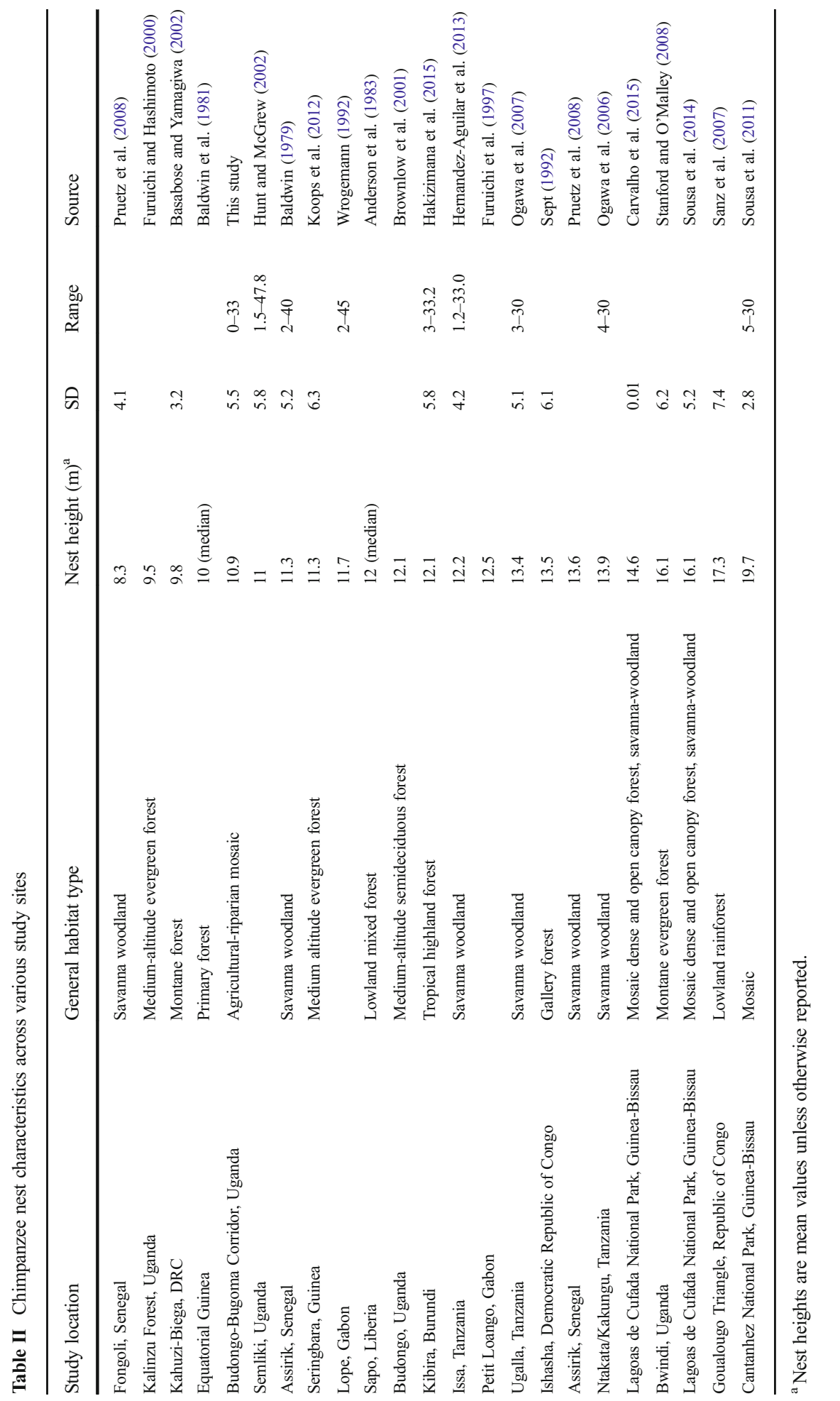


Table III Chimpanzee nest tree species and their relative frequency of use in both fresh nests and total nests, Hoima and Masindi Districts, Uganda, October 2012 to September 2013

\begin{tabular}{|c|c|c|c|c|}
\hline \multirow[t]{2}{*}{ Tree species } & \multicolumn{2}{|c|}{ All nests, regardless of age } & \multicolumn{2}{|c|}{ Fresh nests only } \\
\hline & No. of nests & Prop. of nests & No. of nests & Prop. of nests \\
\hline Eucalyptus grandis & 180 & 0.204 & 66 & 0.135 \\
\hline Macaranga schweinfurthii & 124 & 0.141 & 77 & 0.157 \\
\hline Pseudospondias microcarpa & 75 & 0.085 & 50 & 0.102 \\
\hline Tabernaemontana pachysiphon & 34 & 0.039 & 18 & 0.037 \\
\hline Oxyanthus speciosus & 29 & 0.033 & 8 & 0.016 \\
\hline Mitragyna stipulosa & 28 & 0.032 & 20 & 0.041 \\
\hline Funtumia africana & 19 & 0.022 & 17 & 0.035 \\
\hline Phoenix reclinata & 17 & 0.019 & 9 & 0.018 \\
\hline Pycnanthus angolensis & 15 & 0.017 & 9 & 0.018 \\
\hline Lovoa trichilioides & 12 & 0.014 & 11 & 0.022 \\
\hline Maerua spp. & 12 & 0.014 & 4 & 0.008 \\
\hline Piptadeniastrum africanum & 12 & 0.014 & 12 & 0.025 \\
\hline Myrianthus arboreus & 11 & 0.012 & 7 & 0.014 \\
\hline Rinorea spp. & 11 & 0.012 & 4 & 0.008 \\
\hline Sapium ellipticum & 11 & 0.012 & 2 & 0.004 \\
\hline Morus spp. & 11 & 0.012 & 5 & 0.010 \\
\hline Khaya anthotheca & 10 & 0.011 & 9 & 0.018 \\
\hline Theobroma cacao & 10 & 0.011 & 7 & 0.014 \\
\hline Albizia zygia & 7 & 0.008 & 6 & 0.012 \\
\hline Trilepisium madagascariensis & 6 & 0.007 & 4 & 0.008 \\
\hline Alchornea laxiflora & 6 & 0.007 & 4 & 0.008 \\
\hline Ficus spp. & 6 & 0.007 & 6 & 0.012 \\
\hline Combretum spp. & 5 & 0.006 & 0 & 0.000 \\
\hline Acacia hockii & 4 & 0.005 & 4 & 0.008 \\
\hline Ficus vallis-choudae & 4 & 0.005 & 4 & 0.008 \\
\hline Parkia filicoidea & 4 & 0.005 & 3 & 0.006 \\
\hline Antiaris toxicaria & 3 & 0.003 & 0 & 0.000 \\
\hline Artocarpus heterophyllus & 3 & 0.003 & 1 & 0.002 \\
\hline Cordia millenii & 3 & 0.003 & 2 & 0.004 \\
\hline Cynometra alexandrii & 3 & 0.003 & 1 & 0.002 \\
\hline Ficus natalensis & 3 & 0.003 & 3 & 0.006 \\
\hline Ficus ovata & 3 & 0.003 & 0 & 0.000 \\
\hline Maesopsis eminii & 3 & 0.003 & 3 & 0.006 \\
\hline Trichilia dregeana & 2 & 0.002 & 0 & 0.000 \\
\hline Albizia coriaria & 2 & 0.002 & 2 & 0.004 \\
\hline Aningeria spp. & 2 & 0.002 & 0 & 0.000 \\
\hline Entandrophragma spp. & 2 & 0.002 & 1 & 0.002 \\
\hline Marantochloa leucantha & 2 & 0.002 & 1 & 0.002 \\
\hline Markhamia lutea & 2 & 0.002 & 0 & 0.000 \\
\hline
\end{tabular}


Table III (continued)

\begin{tabular}{|c|c|c|c|c|}
\hline \multirow[t]{2}{*}{ Tree species } & \multicolumn{2}{|c|}{ All nests, regardless of age } & \multicolumn{2}{|c|}{ Fresh nests only } \\
\hline & No. of nests & Prop. of nests & No. of nests & Prop. of nests \\
\hline Sterculia dawei & 2 & 0.002 & 2 & 0.004 \\
\hline Vernonia amagdalena & 2 & 0.002 & 1 & 0.002 \\
\hline Caloncoba schweinfurthii & 1 & 0.001 & 1 & 0.002 \\
\hline Harungana madagascariensis & 1 & 0.001 & 0 & 0.000 \\
\hline Mangifera indica & 1 & 0.001 & $\mathbf{0}$ & 0.000 \\
\hline Pinus caribaea & 1 & 0.001 & $\mathbf{0}$ & 0.000 \\
\hline Psidium guajava & 1 & 0.001 & $\mathbf{0}$ & 0.000 \\
\hline Teclea nobilis & 1 & 0.001 & 1 & 0.002 \\
\hline Saccharum officinarum & 0 & 0.000 & $\mathbf{0}$ & 0.000 \\
\hline Multiple species & 60 & 0.068 & 34 & 0.070 \\
\hline Climbers & 18 & 0.020 & 7 & 0.014 \\
\hline Unknown & 97 & 0.110 & 63 & 0.129 \\
\hline Total & 881 & & 489 & \\
\hline
\end{tabular}

Bold font indicates introduced species

\section{Eucalyptus Bark Feeding}

In addition to extensive evidence for the use of introduced species such as eucalyptus for nesting, we also found evidence that chimpanzees consumed eucalyptus bark (Fig. 3). We encountered stripped eucalyptus bark and bark wadges in five eucalyptus plantations in the study area. We found damage only to the bark of eucalyptus trees; we found no evidence of damage to eucalyptus leaves or flowers, and only superficial damage to phloem (incidental to bark stripping; Fig. 3). These plantations fell within the MCPs of the same two putative chimpanzee communities that nested in eucalyptus (Fig. 4). Over the 12-mo study period, we recorded fresh bark stripping evidence across

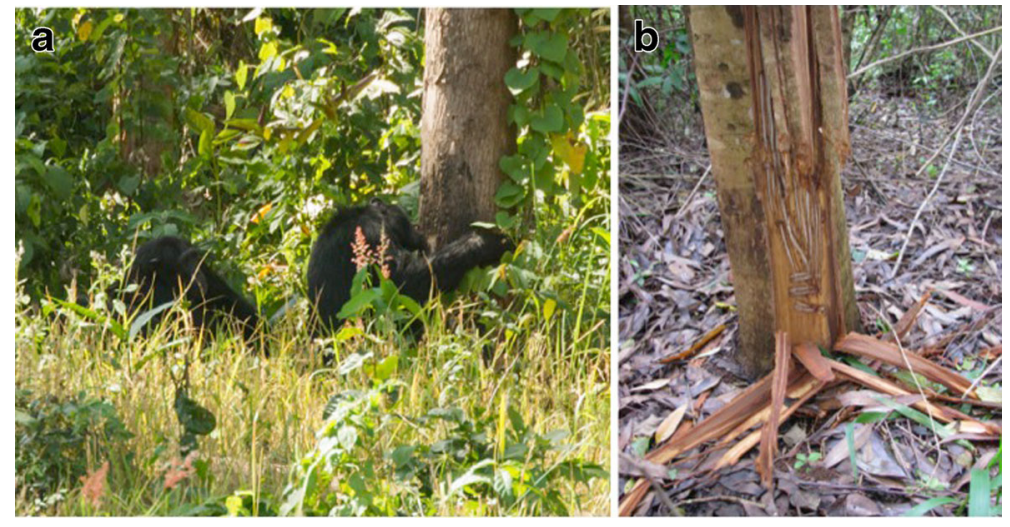

Fig. 3 Chimpanzee eucalyptus bark feeding signs and direct observation, Hoima District, Uganda. (a) Direct observation of eucalyptus bark feeding by a mixed chimpanzee party, January 2013. (b) The base of a eucalyptus tree with evidence of chimpanzee bark stripping. 


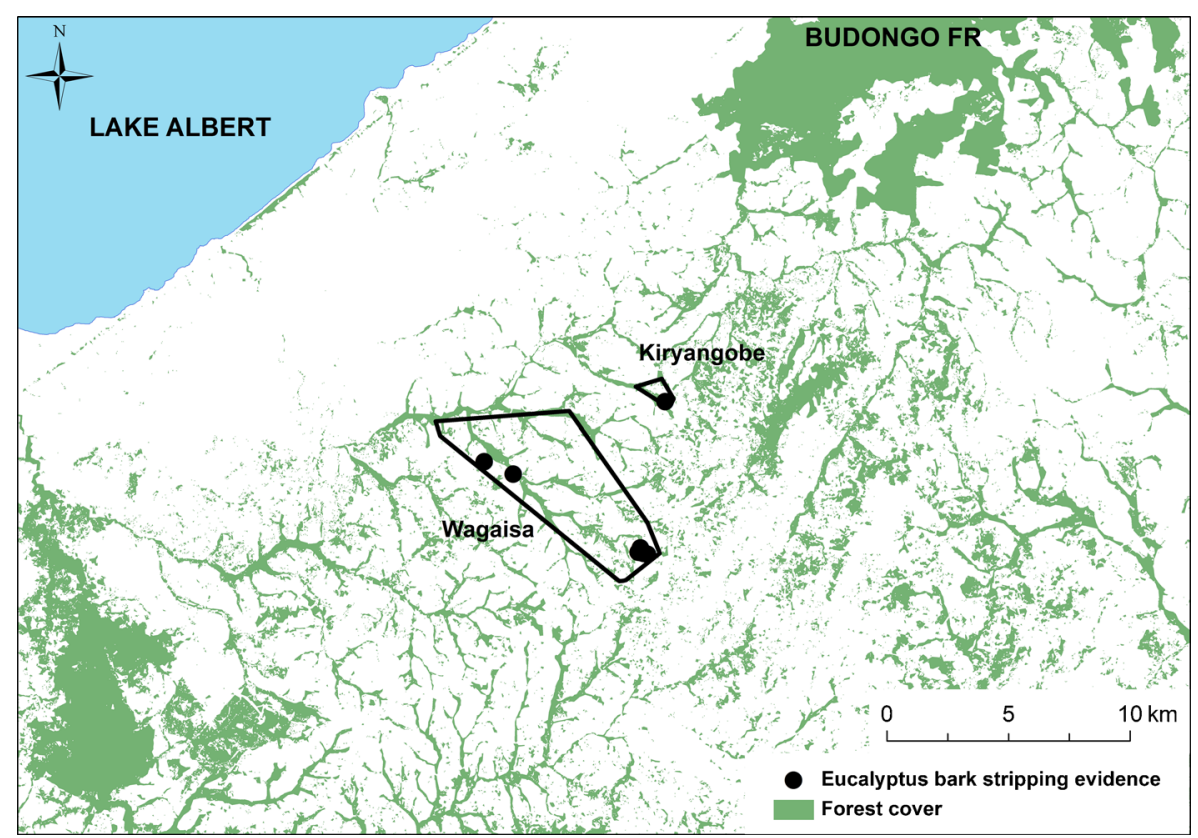

Fig. 4 Locations associated with eucalyptus bark feeding evidence during the study period, October 2012 to September 2013. Black circles indicate the locations of chimpanzee bark feeding evidence or direct observations. MCPs for Wagaisa and Kiryangobe are indicated by polygons. Green indicates forest cover during the study period (Hansen et al. 2013).

five months (October, January, February, March, and July), during both rainy and dry seasons. We also observed this behavior directly on one occasion (Fig. 3).

\section{Discussion}

In accordance with our hypothesis, chimpanzees in a human-dominated habitat displayed a variety of nesting strategies indicating behavioral responses to anthropogenic disturbance. We predicted that nests would occur at low heights or on the ground in this habitat. Mean nest height was approximately $11 \mathrm{~m}$, which was on the lower end of the range of mean observed nest heights across numerous study sites (Table II). This may indicate that fewer tall trees are available, or that chimpanzees sometimes nest at lower heights to avoid detection by their human neighbors, since low nests in swamps and riparian forests are often difficult to see from outside the forest while higher nests are more easily visible from a distance. Alternatively, chimpanzees may prefer nesting at lower heights and may do so more frequently in dense riparian and swamp forests because nest height is less restricted in this habitat type that humans typically avoid entering.

A small percentage ( $2 \%$ ) of overall nests were night ground nests. This percentage falls within the broad range $(0.05-35.4 \%)$ of ground nest rates reported at other sites (reviewed in Tagg et al. 2013). Night ground nesting by chimpanzees in southeast Cameroon was associated with human influence and may help chimpanzees avoid 
human detection in swamps (Tagg et al. 2013). Ground nests in this study area may serve a similar function. Predator pressure may play a key role in the absence of ground nesting at some sites (Pruetz et al. 2008). In this study area, there are no potential predators present aside from humans, which may also permit occasional ground nesting. Future studies may help clarify factors underlying ground nesting behavior in human-disturbed habitats, including the role of human population density in ground nesting variation.

We also predicted that chimpanzees would nest in introduced species, reuse nests, and construct nests from multiple trees. We observed a small but substantial proportion of reused and composite nests. Nest reuse has sometimes been associated with low nest tree availability or a scarcity of trees with fresh leaves for nesting (Fruth and Hohmann 1996; Wrangham 1992), which may explain its occurrence in this habitat with ongoing deforestation. Composite nests may similarly be used due to the scarcity of suitable nest trees, though the use of such nests is not well documented at other study sites. Nest reuse has also been reported to occur more frequently among chimpanzees with snare injuries in the nearby Budongo Forest (Plumptre and Reynolds 1997). Some chimpanzees in this study area also have missing limbs and other injuries from snares and mantraps and may similarly be more likely to reuse nests for this reason (McLennan et al. 2012; Reynolds 2005). Collectively, these findings indicate that chimpanzees are capable of flexibly modifying their nesting strategies in a habitat with shrinking natural forests. These strategies may be driven by necessity, by shifting preferences, or by a combination of factors.

Perhaps most notably, chimpanzees often nested in introduced species. Eucalyptus trees in particular were often used for nest construction, with eucalyptus ranking among the most commonly observed nest tree species. There are several nonmutually exclusive explanations for the common use of eucalyptus for nesting in this region. First, eucalyptus may be used frequently because of its high availability relative to other tree species in the habitat. It was beyond the scope of this study to examine the availability and distribution of nest tree species systematically. Nonetheless, satellite imagery suggested that eucalyptus is overrepresented as a nest tree species given its availability in the habitat. In addition, eucalyptus plantations with nests were typically located in relatively close proximity to natural forest patches; $c a$. $50 \mathrm{~m}$ away on average. This indicates that a mere lack of nearby natural forest cannot account for the prevalence of eucalyptus nesting.

Instead, a second potential reason for the high frequency of eucalyptus nesting is that eucalyptus plantations provide easy access to fragments of natural forest that contain important natural food resources. Similarly, cultivars such as jackfruit were sometimes found in close proximity to eucalyptus plantations, which may indicate that eucalyptus acted as a convenient nest species for cultivar feeding. We found widespread evidence that chimpanzees in this habitat consumed cultivars such as jackfruit during the study period, which supports this potential role for eucalyptus nesting (M. McCarthy, unpubl. data). Other researchers have similarly suggested that nesting preferences may be driven partially by the close proximity of valuable fruit trees (Brownlow et al. 2001; Goodall 1962; Stanford and O’Malley 2008).

Third, eucalyptus may also be used frequently for nesting due to comfort. Pliable branches and small leaves have been identified as potentially important components for nest comfort (Goodall 1962; Hernandez-Aguilar 2009; van Casteren et al. 2012). 
Eucalyptus trees have small leaves, which may make them more comfortable for nesting than some other available tree species. However, the second and third most common nest tree species, Macaranga schweinfurthii and Pseudospondias microcarpa, typically produce rather large leaves, which may indicate that leaf size does not generally play an important role in nest tree choice. Eucalyptus branches are relatively thin and therefore are likely to be highly pliable, which may suggest eucalyptus makes for comfortable nests, though the physical properties of the branches have not been tested.

Lastly, eucalyptus may be used for nesting because it has antivector properties, which have also been proposed as an important factor influencing chimpanzee nest choice (Koops et al. 2012; Samson et al. 2013; Stewart 2011). Although the antivector properties of eucalyptus are widely recognized (Ebrahimi et al. 2013), the potential for eucalyptus nests to repel insects more effectively than nests constructed in other available tree species needs to be tested.

In addition to nesting in eucalyptus trees, chimpanzees also stripped and wadged the bark of eucalyptus trees in this region. We found fresh eucalyptus bark feeding traces and as well as directly observing this behavior. Numerous primate taxa incorporate bark into their diets (Nishida 1976), and eucalyptus bark feeding in particular has previously been observed in colobus monkeys, mountain gorillas, and Bornean orangutans (Meijaard et al. 2010; Rode et al. 2003; Rothman et al. 2006; Wasserman et al. 2012). This study adds chimpanzees to the species of anthropoid primates known to consume eucalyptus bark.

There are several reasons why chimpanzees may consume eucalyptus bark in this habitat. First, eucalyptus may serve as a fallback food. Nishida (1976) reported that tree bark of certain natural tree species served as a fallback food for chimpanzees in the Mahale Mountains, Tanzania during periods of low resource availability. In this study, we did not measure resource availability throughout the habitat and could not test this hypothesis rigorously. However, given the fact that eucalyptus bark consumption occurred at various times throughout the year, in both rainy and dry seasons, and given the relatively low availability of this resource, this explanation seems unlikely. Additionally, we found no evidence for bark feeding in other tree species, indicating that eucalyptus was likely not part of a broader pattern of bark consumption during periods of low resource availability.

Second, eucalyptus may serve a medicinal purpose. Eucalyptus leaves are used by people in Uganda and elsewhere as a treatment for cough (Namukobe et al. 2011). Although chimpanzees use numerous plant species for medicinal purposes (Huffman 2001; Masi et al. 2012), eucalyptus has not been among those recorded species to date, and its potential use for medicinal purposes in chimpanzees has not been evaluated.

A third possibility is that chimpanzees consume eucalyptus bark because of its high mineral content. In particular, eucalyptus bark consumption in mountain gorillas and colobus monkeys has been attributed to its particularly high sodium content (Nkurunungi 2004; Rode et al. 2003; Rothman et al. 2006; Wasserman et al. 2012). Eucalyptus bark also contains secondary compounds such as phytoestrogens, however, which may act as endocrine disruptors or potentially have other detrimental effects on consumers (Wasserman et al. 2012, 2013). The effects of eucalyptus secondary compounds on chimpanzees are currently not known. 
Chimpanzees in this fragmented forest landscape use introduced species, in particular eucalyptus, for both nesting and feeding. Eucalyptus may be used due to its relative availability as a nesting and feeding resource, or for a variety of other nonmutually exclusive reasons. Interestingly, these behaviors were observed in just two putative chimpanzee communities during the study period despite the presence of eucalyptus plantations in other areas of chimpanzee habitat use. More recently, eucalyptus nesting and bark consumption has also been observed at a third site in the survey region, Bulindi (M. McLennan, pers. comm.). This variation may reflect differences in search effort or a relatively higher availability of eucalyptus in communities that use it. It could also potentially reflect local community-level variation in behavioral traditions for chimpanzee communities introduced to novel resources. Further studies may help clarify both the role of introduced species and the potential of these species to support great apes in degraded habitats. Given the increasing prevalence of such habitats throughout the geographic ranges of great apes, introduced species are likely to become increasingly relied on in remaining populations. Rather than representing rare and novel behavioral variants, the use of such species may become the norm for some surviving great ape populations in degraded habitats of the Anthropocene. The potential for such behavioral flexibility to support the long-term persistence of great apes in degraded habitats remains highly uncertain, however.

Acknowledgments Open access funding provided by Max Planck Society. We thank the Uganda National Council for Science and Technology, the Uganda Wildlife Authority, and the National Forestry Authority for permission to conduct this research. This study was funded by the American Society of Primatologists; the University of Southern California Jane Goodall Research Center and Dornsife College of Letters, Arts, and Sciences; the Nacey Maggioncalda Foundation; and Primate Conservation, Inc. For assistance during field work, we thank Matthew McLennan, Nicholas Rugadya, Tom Sabiiti, Moses Ssemahunge, and Emily Stewart. This manuscript was improved by helpful comments from Matthew McLennan, Noemi Spagnoletti, Kimberley Hockings, and two anonymous reviewers.

Open Access This article is distributed under the terms of the Creative Commons Attribution 4.0 International License (http://creativecommons.org/licenses/by/4.0/), which permits unrestricted use, distribution, and reproduction in any medium, provided you give appropriate credit to the original author(s) and the source, provide a link to the Creative Commons license, and indicate if changes were made.

\section{References}

Ainembabazi, J. H., \& Angelsen, A. (2014). Do commercial forest plantations reduce pressure on natural forests? evidence from forest policy reforms in Uganda. Forest Policy and Economics, 40, 48-56.

Ancrenaz, M., Sollmann, R., Meijaard, E., Hearn, A. J., Ross, J., et al. (2014). Coming down from the trees: is terrestrial activity in Bornean orangutans natural or disturbance driven? Scientific Reports, 4, 1-5.

Ancrenaz, M., Oram, F., Ambu, L., Lackman, I., Ahmad, E., et al. (2015). Of Pongo, palms and perceptions: a multidisciplinary assessment of Bornean orang-utans Pongo pygmaeus in an oil palm context. Oryx, 49, 465-472.

Anderson, J. R., Williamson, E. A., \& Carter, J. (1983). Chimpanzees of Sapo Forest, Liberia: density, nests, tools and meat-eating. Primates, 24, 594-601.

Baldwin, P. J. (1979). The natural history of the chimpanzee (Pan troglodytes verus), at Mt. Senegal. Assirik: University of Stirling.

Baldwin, P. J., Sabater Pi, J., McGrew, W. C., \& Tutin, C. (1981). Comparisons of nests made by different populations of chimpanzees (Pan troglodytes). Primates, 22, 474-486. 
Basabose, A. K., \& Yamagiwa, J. (2002). Factors affecting nesting site choice in chimpanzees at Tshibati, Kahuzi-Biega National Park: influence of sympatric gorillas. International Journal of Primatology, 23, 263-282.

Bessa, J., Sousa, C., \& Hockings, K. J. (2015). Feeding ecology of chimpanzees (Pan troglodytes verus) inhabiting a forest-mangrove-savanna-agricultural matrix at Caiquene-Cadique, Catanhez National Park, Guinea-Bissau. American Journal of Primatology, 77, 651-665.

Brownlow, A. R., Plumptre, A. J., Reynolds, V., \& Ward, R. (2001). Sources of variation in the nesting behavior of chimpanzees (Pan troglodytes schweinfurthii) in the Budongo forest, Uganda. American Journal of Primatology, 55, 49-55.

Campbell-Smith, G., Campbell-Smith, M., Singleton, I., \& Linkie, M. (2011). Apes in space: Saving an imperilled orangutan population in Sumatra. PLOS ONE, 6, e17210.

Carvalho, J. S., Meyer, C. F. J., Vicente, L., \& Marques, T. A. (2015). Where to nest? ecological determinants of chimpanzee nest abundance and distribution at the habitat and tree species scale. American Journal of Primatology, 77, 186-199.

CIA (Ed.). (2013). The World Factbook 2013-14. http://www.cia.gov/library/publications/the-worldfactbook/index.html (Accessed September 14, 2015).

Cibot, M., Bortolamiol, S., Seguya, A., \& Krief, S. (2015). Chimpanzees facing a dangerous situation: a hightraffic asphalted road in the Sebitoli area of Kibale National Park, Uganda. American Journal of Primatology, 77, 890-900.

Ebrahimi, M., Safaralizade, M. H., Valizadegan, O., \& Amin, B. H. H. (2013). Efficacy of three plant essential oils, Azadirachta indica (Adr. Juss.), Eucalyptus camaldulensis (Dehn.) and Laurus nobilis (L.) on mortality cotton aphids, Aphis gossypii Glover (Hem: Aphididae). Archives of Phytopathology and Plant Protection, 46, 1093-1101.

Eggeling, W. J. (1947). Observations on the ecology of the Budongo Rain Forest, Uganda. Journal of Ecology, $34,20-87$.

FAO. (2010). Global forest resources assessment 2010: Country report, Uganda. Rome: Food and Agriculture Organization of the United Nations.

Fruth, B., \& Hohmann, G. (1996). Nest building behavior in the great apes: The great leap forward? In W. C. McGrew, L. F. Marchant, \& T. Nishida (Eds.), Great ape societies (pp. 225-240). Cambridge: Cambridge University Press.

Furuichi, T., \& Hashimoto, C. (2000). Ground beds of chimpanzees in the Kalinzu Forest, Uganda. Pan Africa News, 7.

Furuichi, T., Inagaki, H., \& Angoue-Ovono, S. (1997). Population density of chimpanzees and gorillas in the Petit Loango Reserve, Gabon: employing a new method to distinguish between nests of the two species. International Journal of Primatology, 18, 1029-1046.

Goodall, J. (1962). Nest building behavior in the free ranging chimpanzee. Annals of the New York Academy of Science, 102, 455-467.

Hakizimana, D., Hambuckers, A., \& Brotcorne, F. (2015). Characterization of nest sites of chimpanzees (Pan troglodytes schweinfurthii) in Kibira National Park, Burundi. African Primates, 10, 1-12.

Hansen, M. C., Potapov, P. V., Moore, R., Hancher, M., Turubanova, S. A., et al. (2013). High-resolution global maps of 21st-century forest cover change. Science, 342, 850-853.

Hernandez-Aguilar, R. A. (2009). Chimpanzee nest distribution and site reuse in a dry habitat: implications for early hominin ranging. Journal of Human Evolution, 57, 350-364.

Hernandez-Aguilar, R. A., Moore, J., \& Stanford, C. B. (2013). Chimpanzee nesting patterns in savanna habitat: environmental influences and preferences. American Journal of Primatology, 75, 979-994.

Hicks, T. C. (2010). A chimpanzee mega-culture? Exploring behavioral continuity in Pan troglodytes schweinfurthii across northern DR Congo. Doctoral thesis, University of Amsterdam.

Hockings, K. J., \& McLennan, M. R. (2012). From forest to farm: systematic review of cultivar feeding by chimpanzees - management implications for wildlife in anthropogenic landscapes. PLoS ONE, 7, e33391.

Hockings, K. J., Anderson, J. R., \& Matsuzawa, T. (2009). Use of wild and cultivated foods by chimpanzees at Bossou, Republic of Guinea: feeding dynamics in a human-influenced environment. American Journal of Primatology, 71, 636-646.

Hockings, K. J., Anderson, J. R., \& Matsuzawa, T. (2012). Socioecological adaptations by chimpanzees, Pan troglodytes verus, inhabiting an anthropogenically impacted habitat. Animal Behaviour, 83, 801-810.

Hockings, K. J., McLennan, M. R., Carvalho, S., Ancrenaz, M., Bobe, R., et al. (2015). Apes in the Anthropocene: Flexibility and survival. Trends in Ecology \& Evolution, 30, 215-222.

Huffman, M. A. (2001). Self-medicative behavior in the African great apes: an evolutionary perspective into the origins of human traditional medicine. BioScience, 51, 651-661. 
Hunt, K. D., \& McGrew, W. C. (2002). Chimpanzees in the dry habitats of Assirik, Senegal and Semliki Wildlife Reserve, Uganda. In C. Boesch, G. Hohmann, \& L. F. Marchant (Eds.), Behavioural diversity in chimpanzees and bonobos (pp. 35-51). Cambridge: Cambridge University Press.

Koops, K., Humle, T., Sterck, E. H. M., \& Matsuzawa, T. (2007). Ground-nesting by the chimpanzees of the Nimba Mountains, Guinea: environmentally or socially determined? American Journal of Primatology, $69,407-419$.

Koops, K., McGrew, W. C., de Vries, H., \& Matsuzawa, T. (2012). Nest-building by chimpanzees (Pan troglodytes verus) at Seringbara, Nimba Mountains: antipredation, thermoregulation, and antivector hypotheses. International Journal of Primatology, 33, 356-380.

Krief, S., Cibot, M., Bortolamiol, S., Seguya, A., Krief, J.-M., \& Masi, S. (2014). Wild chimpanzees on the edge: nocturnal activities in croplands. PLOS ONE, 9, e109925.

Langdale-Brown, I., Osmaston, H. A., \& Wilson, J. G. (1964). The vegetation of Uganda and its bearing on land use. Entebbe: Government Printer.

Last, C., \& Muh, B. (2013). Effects of human presence on chimpanzee nest location in the Lebialem-Mone Forest Landscape, Southwest Region, Cameroon. Folia Primatologica, 84, 51-63.

Masi, S., Gustafsson, E., Saint Jalme, M., Narat, V., Todd, A., et al. (2012). Unusual feeding behavior in wild great apes, a window to understand origins of self-medication in humans: role of sociality and physiology on learning process. Physiology \& Behavior, 105, 337-349.

McCarthy, M. S., Lester, J. D., Howe, E. J., Arandjelovic, M., Stanford, C. B., \& Vigilant, L. (2015). Genetic censusing identifies an unexpectedly sizeable population of an endangered large mammal in a fragmented forest landscape. BMC Ecology, 15, 21.

McLennan, M. R. (2008). Beleaguered chimpanzees in the agricultural district of Hoima, western Uganda. Primate Conservation, 23, 45-54.

McLennan, M. R. (2013). Diet and feeding ecology of chimpanzees (Pan troglodytes) in Bulindi, Uganda: foraging strategies at the forest-farm interface. International Journal of Primatology, 34, 585-614.

McLennan, M. R., \& Hill, C. M. (2012). Troublesome neighbors: Changing attitudes towards chimpanzees (Pan troglodytes) in a human-dominated landscape in Uganda. Journal for Nature Conservation, 20, 219-227.

McLennan, M. R., Hyeroba, D., Asiimwe, C., Reynolds, V., \& Wallis, J. (2012). Chimpanzees in mantraps: lethal crop protection and conservation in Uganda. Oryx, 46, 598-603.

Meijaard, E., Albar, G., Nardiyono, R. Y., Ancrenaz, M., \& Spehar, S. (2010). Unexpected ecological resilience in Bornean orangutans and implications for pulp and paper plantation management. PLoS ONE, 5, e12813.

Mwavu, E. N., \& Witkowski, E. T. F. (2008). Land-use and cover changes (1988-2002) around Budongo Forest Reserve, NW Uganda: implications for forest and woodland sustainability. Land Degradation \& Development, 19, 606-622.

MWLE. (2002). The national forest plan. Kampala: Ministry of Water, Lands, and Environment.

Namukobe, J., Kasenene, J. M., Kiremire, B. T., Byamukama, R., Kamatenesi-Mugisha, M., et al. (2011). Traditional plants used for medicinal purposes by local communities around the Northern sector of Kibale National Park, Uganda. Journal of Ethnopharmacology, 136, 236-245.

Nishida, T. (1976). The bark-eating habits in primates, with special reference to their status in the diet of wild chimpanzees. Folia Primatologica, 25, 277-287.

Nkurunungi, J. B. (2004). Feeding and ranging ecology of gorillas (Gorilla gorilla beringei) in Bwindi Impenetrable National Park. Doctoral thesis, Makerere University.

Ogawa, H., Moore, J., \& Kamenya, S. (2006). Chimpanzees in the Ntakata and Kakungu areas, Tanzania. Primate Conservation, 21, 97-101.

Ogawa, H., Idani, G., Moore, J., Pintea, L., \& Hernandez-Aguilar, A. (2007). Sleeping parties and nest distribution of chimpanzees in the savanna woodland, Ugalla, Tanzania. International Journal of Primatology, 28, 1397-1412.

Plumptre, A. J., \& Reynolds, V. (1997). Nesting behavior of chimpanzees: implications for censuses. International Journal of Primatology, 18, 475-485.

Pruetz, J. D., Fulton, S. J., Marchant, L. F., McGrew, W. C., Schiel, M., \& Waller, M. (2008). Arboreal nesting as anti-predator adaptation by savanna chimpanzees (Pan troglodytes verus) in southeastern Senegal. American Journal of Primatology, 70, 393-401.

Quantum GIS. (2014). Quantum GIS Geographic Information System. Open Source Geospatial Foundation Project. http:/qgis.osgeo.org.

Reynolds, V. (2005). Chimpanzees of the Budongo Forest. New York: Oxford University Press.

Rode, K. D., Chapman, C. A., \& Chapman, L. J. (2003). Mineral resource availability and consumption by colobus in Kibale National Park, Uganda. International Journal of Primatology, 24, 541-573. 
Rothman, J. M., Van Soest, P. J., \& Pell, A. N. (2006). Decaying wood is a sodium source for mountain gorillas. Biology Letters, 2, 321-324.

Samson, D. R., Muehlenbein, M. P., \& Hunt, K. D. (2013). Do chimpanzees (Pan troglodytes schweinfurthii) exhibit sleep related behaviors that minimize exposure to parasitic arthropods? a preliminary report on the possible anti-vector function of chimpanzee sleeping platforms. Primates, 54, 73-80.

Sanz, C., Morgan, D., Strindberg, S., \& Onononga, J. R. (2007). Distinguishing between the nests of sympatric chimpanzees and gorillas. Journal of Applied Ecology, 44, 263-272.

Sept, J. M. (1992). Was there no place like home? a new perspective on early hominid archaeological sites from the mapping of chimpanzee nests. Current Anthropology, 33, 187-207.

Sousa, J., Barata, A. V., Sousa, C., Casanova, C. C. N., \& Vicente, L. (2011). Chimpanzee oil-palm use in southern Cantanhez National Park, Guinea-Bissau. American Journal of Primatology, 73, 485-497.

Sousa, J., Casanova, C., Barata, A. V., \& Sousa, C. (2014). The effect of canopy closure on chimpanzee nest abundance in Lagoas de Cufada National Park, Guinea-Bissau. Primates, 55, 283-292.

Stanford, C. B., \& O’Malley, R. C. (2008). Sleeping tree choice by Bwindi chimpanzees. American Journal of Primatology, 70, 642-649.

Stewart, F. A. (2011). Brief communication: Why sleep in a nest? empirical testing of the function of simple shelters made by wild chimpanzees. American Journal of Physical Anthropology, 146, 313-318.

Tagg, N., Willie, J., Petre, C.-A., \& Haggis, O. (2013). Ground night nesting in chimpanzees: new insights from central chimpanzees (Pan troglodytes troglodytes) in South-East Cameroon. Folia Primatologica, $84,362-383$.

Turyahabwe, N., \& Banana, A. Y. (2008). An overview of history and development of forest policy and legislation in Uganda. International Forestry Review, 10, 641-656.

Tutin, C., \& Fernandez, M. (1984). Nationwide census of gorilla (Gorilla g. gorilla) and chimpanzee (Pan $t$. troglodytes) populations in Gabon. American Journal of Primatology, 6, 313-336.

Twongyirwe, R., Bithell, M., Richards, K. S., \& Rees, W. G. (2015). Three decades of forest cover change in Uganda's Northern Albertine Rift. Land Use Policy, 49, 236-251.

UBOS. (2014). NPHC 2014 provisional results report (pp. 1-73). Kampala: Uganda Bureau of Statistics.

van Casteren, A., Sellers, W. I., Thorpe, S. K. S., Coward, S., Crompton, R. H., et al. (2012). Nest-building orangutans demonstrate engineering know-how to produce safe, comfortable beds. Proceedings of the National Academy of Sciences of the USA, 109, 6873-6877.

Wasserman, M. D., Taylor-Gutt, A., Rothman, J. M., Chapman, C. A., Milton, K., \& Leitman, D. C. (2012). Estrogenic plant foods of red colobus monkeys and mountain gorillas in Uganda. American Journal of Physical Anthropology, 148, 88-97.

Wasserman, M. D., Milton, K., \& Chapman, C. A. (2013). The roles of phytoestrogens in primate ecology and evolution. International Journal of Primatology, 34, 861-878.

Wrangham, R. W. (1992). Comment on Sept, J. M., 1992, was there no place like home? a new perspective on early hominid archaeological sites from the mapping of chimpanzee nests. Current Anthropology, 33, 201-202.

Wrogemann, D. (1992). Wild chimpanzees in Lope, Gabon: Census-method and habitat use. Bremen University. 